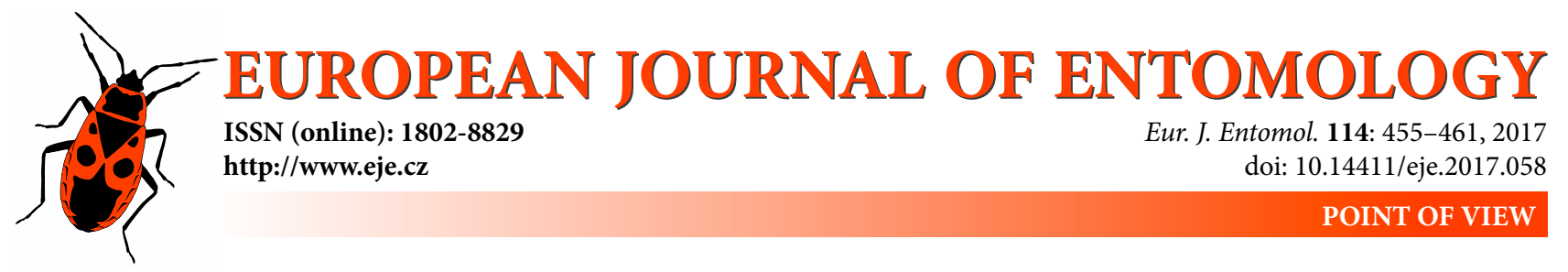

\title{
Harmonia axyridis (Coleoptera: Coccinellidae): Smelling the rat in native ladybird declines
}

\author{
JOHN J. SLOGGETT \\ Maastricht Science Programme, Maastricht University, P.O. Box 616, 6200 MD Maastricht, The Netherlands; \\ e-mail: j.sloggett@maastrichtuniversity.nl
}

\begin{abstract}
Key words. Coleoptera, Coccinellidae, Adalia bipunctata, Harmonia axyridis, alien invasive, habitat compression, native species decline, urbanization
\end{abstract}

\begin{abstract}
In the last two decades a huge amount of research has focused on the invasive harlequin ladybird, Harmonia axyridis, particularly on potential or actual deleterious effects that have arisen after it has colonised new regions. A focus of this work has been real or anticipated declines in native ladybird abundance since the introduction of $H$. axyridis, for which it is deemed responsible. Scientists have generally painted a very bleak picture of the effects of $H$. axyridis on native species: in this paper I argue that the picture painted is often too bleak. I use the case of the 2-spot ladybird, Adalia bipunctata, the species most often invoked as threatened by $H$. axyridis, to illustrate my point. While there is little question that $H$. axyridis has led to a decline in $A$. bipunctata populations in Europe, it seems likely that prior to the invasive ladybird's arrival $A$. bipunctata occurred in artificially high numbers in the urban environments in which it was typically studied. Pollution in towns and cities led to enhanced numbers of prey aphids on plants there which initially favoured $A$. bipunctata, and later $H$. axyridis. Thus one species, $A$. bipunctata, that has benefitted from an association with humans has been replaced by another, $H$. axyridis, just as brown rats replaced black rats in Europe and North America. Viewed with a longer perspective, A. bipunctata has more likely declined back to pre-industrial levels: the artificially high level from which it has declined recently was not a 'natural' one, and thus its decline from this level does not imply that it is now threatened or endangered. More broadly, we need a wider perspective, encompassing other ladybirds, longer timeframes and better comparisons with other (non-ladybird) invasive species to more clearly assess whether $\mathrm{H}$. axyridis really poses as much of a threat as is often proposed.
\end{abstract}

\section{INTRODUCTION}

In the last two decades, a huge amount of research has focused on just one species of ladybird, the invasive Asian species Harmonia axyridis (Pallas) (Sloggett, 2005, 2012; Roy et al., 2016). A lot of this research has documented its rapid spread outside its native range and potential or actual deleterious effects on other species in the areas it has colonised (reviewed in Koch, 2003; Majerus et al., 2006; Koch \& Galvan, 2008; Sloggett, 2012; Roy \& Brown, 2015; Roy et al., 2016). The ladybird has often appeared in a very bad light, both over its interactions with humans (e.g., McCutcheon \& Scott, 2001; Goetz, 2009; Linder et al., 2009) and other organisms (e.g., Koch et al., 2006; Roy et al., 2012; Howe et al., 2015).

The effects of invasive $H$. axyridis on native ladybirds have received particular attention. The focus of this work has been actual or anticipated declines in native species abundance since the introduction of $H$. axyridis (e.g., Michaud, 2002; Martins et al., 2009; Adriaens et al., 2010; Roy et al., 2012, 2016; Grez et al., 2016), although the detailed picture is complex (Harmon et al., 2007; Bahlai et al., 2015). This focus has been coupled to numerous ex- periments demonstrating strong intraguild predation of native species by $H$. axyridis in the laboratory and field (e.g., Cottrell \& Yeargan 1998a, b; Yasuda et al., 2004; Ware \& Majerus, 2008; Thomas et al., 2013; Rondoni et al., 2015), although competitive displacement could be more significant in explaining native species' declines (Harmon et al., 2007; Snyder, 2009; Bahlai et al., 2015).

In spite of the underlying complexity involved, the picture painted of the effects of $H$. axyridis on other coccinellids is generally bleak. This negative view has exerted an influence on the general public, often via the press (e.g., Roy et al., 2006), and on policy makers (Ehlers, 2011; Klapwijk, 2013). Gozlan et al. (2013) found that of five non-native species, $H$. axyridis was the most researched in Britain, although it was assessed by them as only the third-ranked ecological threat. All these observations argue for the best possible assessment of the threat posed by $H$. axyridis. In this paper, I argue that the picture painted is too bleak. To illustrate this point, I look at one case of an $H$. axyridis-associated native ladybird decline in detail, that of the 2-spot ladybird, Adalia bipunctata (L.). This species is often argued to be most at threat from $H$. axyridis. I use 
personal observations and data from before and after the arrival of $H$. axyridis in its European range to argue that our perception of how dangerous $H$. axyridis is to $A$. bipunctata, and by implication other native ladybirds, might be greater than the threat it actually poses.

\section{ADALIA BIPUNCTATA AND ITS INTERACTION WITH HARMONIA AXYRIDIS}

Adalia bipunctata is a small aphidophagous member of the subfamily Coccinellinae, which contains most of the commonly recognised species of ladybirds. The ladybird is a habitat and dietary generalist, exhibiting something of a preference for deciduous trees, though also occurring on low-growing plants such as nettles and beans (e.g., Majerus, 1994; Honěk \& Hodek, 1996). The species is of Holarctic distribution. Prior to the arrival of $H$. axyridis, it was an extremely common species in Europe. Its status as a native of North America is unclear although it is not a very recent arrival (Krafsur et al., 1996); furthermore, the possible roles of other invasive coccinellids, notably Coccinella septempunctata L., in its decline in North America (Harmon et al., 2007) make discussion of the situation there more complex. I therefore largely restrict my discussion in this paper to European populations of $A$. bipunctata.

Prior to the arrival of invasive $H$. axyridis, in Europe at least, $A$. bipunctata was one of the most extensively studied ladybird models (Sloggett, 2005). In large part this was due to numerous studies of its genetic colour pattern polymorphism (reviewed in Majerus, 1994; Sloggett \& Honěk, 2012), but studies ranged widely over many other areas of ladybird biology including mating and reproduction, chemical defence, foraging and feeding, and host-parasite interactions (Majerus, 1994; Omkar \& Pervez, 2005; Sloggett, 2005; Hodek et al., 2012).

There is no doubt that $H$. axyridis has had a strong deleterious effect on $A$. bipunctata, even though some populations had apparently been declining prior to its arrival (see discussion). Five years after the arrival of $H$. axyridis, $A$. bipunctata had declined by $30 \%$ in Belgium and by $44 \%$ in the UK, where previously it had been increasing (Roy et al., 2012). Harmonia axyridis shows a strong habitat overlap with $A$. bipunctata, being also a generalist with a preference for deciduous trees (Majerus et al., 2006; Adriaens et al., 2008). A number of studies have documented asymmetric intraguild predation in favour of $H$. axyridis over $A$. bipunctata in the laboratory (e.g., Ware \& Majerus, 2008; Katsanis et al., 2013) and intraguild predation of $A$. bipunctata by $H$. axyridis has also been demonstrated in the field (e.g., Hautier et al., 2011; Thomas et al., 2013): this has been suggested as a cause for the decline of $A$. bipunctata.

The fate of $A$. bipunctata has drawn considerable attention beyond the research community. Based on IUCN Red List criteria, the species was classed as "Vulnerable" in Flanders (Belgium) due to its declining numbers (Adriaens et al., 2015). In France an economic evaluation of willingness to compensate for the effects of $H$. axyridis, suggested that individual households would be prepared to pay annually between $€ 8.60$ and $€ 11.40$ to preserve A. bipunctata; this amounts to a total budget of $€ 198$ million to $€ 266$ million per year (Chakir et al., 2016).

\section{URBANISATION AND LADYBIRDS}

There is good, though scattered, evidence that manmade environments favour certain ladybirds. Such habitats include not only agricultural ecosystems (Honěk, 2012), but also urban and industrial habitats (e.g., Kozlov, 2015; Akkermans, 2016; Egerer et al., 2017). Aphids are known to benefit from the presence of humans, reaching high densities on plants suffering from the effects of pollution: this can lead to high aphid populations in urban areas (Bell et al., 1993), perhaps further exacerbated by higher temperatures in towns (Dale \& Frank, 2014). Such resource availability increases the size of ladybird populations, especially of generalist species, which prefer high aphid densities (see Sloggett, 2008).

Urban areas are suggested to be important in the establishment of new ladybird species (e.g., Kaneko, 2013; Kawakami et al., 2016), and this is certainly true for $H$. axyridis (e.g., Adriaens et al., 2008; Purse et al., 2015; Veran et al., 2016). Explanations for the effects of urbanisation include that $H$. axyridis finds suitable overwintering sites inside buildings and suitable foraging habitats or aphid host plants, such as lime (Tilia spp.) and sycamore (Acer pseudoplatanus L.) (Brown et al., 2008; Purse et al., 2015; Veran et al., 2016). It seems highly likely that human changes to the environment, resulting in higher aphid densities in urban and other anthropogenic habitats have favoured this large voracious ladybird (e.g., see Mukwevho et al., 2017). Fig. 1a shows numbers of $H$. axyridis collected from lime trees in the Dutch city of Eindhoven and the surrounding region; limes support significant populations of aphids (Eucallipterus tiliae L.), which are increased in urban areas (Carter, 1992; Wilkaniec et al., 2013). Twice as many $H$. axyridis were recorded at the central site as in suburban and rural areas. Artificially long persistence of city aphid populations at high levels (e.g., see Wilkaniec et al., 2013) likely also leads to a long potential breeding season, favouring $H$. axyridis, which can produce several generations a year (e.g. Adriaens et al., 2008). In central Eindhoven, in 2016, $H$. axyridis larvae could still be found on limes into November.

However, the same was true for A. bipunctata before the arrival of $H$. axyridis. An extreme example was seen in London in the late 1990s. In 1999, I participated in a study of $A$. bipunctata, covering central London and its suburbs (Welch et al., 2001). Here, pollution or high temperatures favoured long-lasting aphid populations in the centre of the city, most notably E. tiliae on lime trees, which also harboured $A$. bipunctata. Like $H$. axyridis, $A$. bipunctata reached very high numbers in the central city and exhibited an altered phenology, breeding late into the year. In October 1999, I was able to collect abundant $A$. bipunctata adults and larvae from limes at Finsbury Park in North London $\left(51.57^{\circ} \mathrm{N}, 0.10^{\circ} \mathrm{W}\right)$. Although perhaps less pronounced, the same appears to have been true for A. bipunctata in other 


\section{(a) Harmonia axyridis}

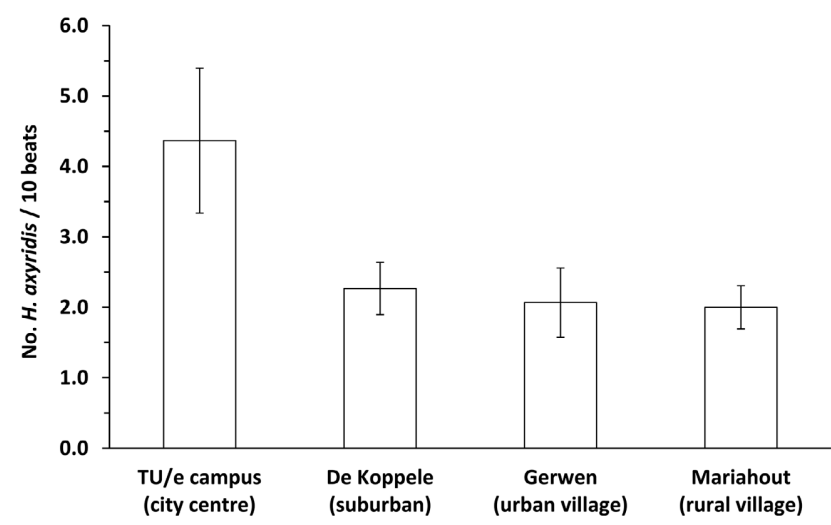

(b) Adalia bipunctata

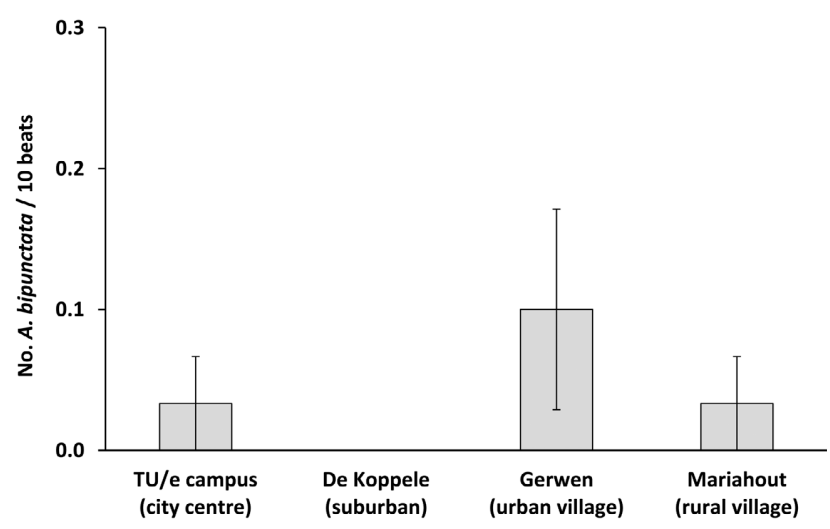

Fig. 1. Numbers of adult Harmonia axyridis (a) and Adalia bipunctata (b) collected on lime trees (Tilia spp.) at four sites in and around the city of Eindhoven, The Netherlands, on $26^{\text {th }}$ August 2016. From left to right, sites are at an increasing distance from central Eindhoven in a north-easterly direction, with distance from central site (TU Eindhoven campus $51.4492^{\circ} \mathrm{N}, 5.4947^{\circ} \mathrm{E}$ ): De Koppele $\left(51.4810^{\circ} \mathrm{N}, 5.4910^{\circ} \mathrm{E}\right) 3.5 \mathrm{~km}$; Gerwen $\left(51.4885^{\circ} \mathrm{N}, 5.5645^{\circ} \mathrm{E}\right) 7$ $\mathrm{km}$; Mariahout $\left(51.5410^{\circ} \mathrm{N}, 5.5705^{\circ} \mathrm{E}\right) 12 \mathrm{~km}$. Tree branches were beaten using a one-metre long stick and beating tray ten times and ladybirds counted on the beating tray; this was carried out on three different areas of the reachable canopy ( $\leq$ approx. $3 \mathrm{~m}$ height) of each tree; ten trees were beaten at each site. Values given here are Mean $\pm S$.E. of mean values for the three areas of each tree. For $H$. axyridis, a one-way ANOVA across the four sites was carried out, using each of the three areas of each tree as repeated measures and Type III sum of squares in SPSS 24: $F_{3,36}=3.362, P$ $=0.029$. No such analysis was carried out for $A$. bipunctata as the numbers of ladybirds were so low, being between a total of zero and three at each site (note that the $y$-axis is $1 / 20$ the scale of the $H$. axyridis graph).

European urban areas (e.g., Timoféeff-Ressovsky, 1940; Czechowska \& Bielawski, 1981; Brakefield, 1984).

This does not appear to be the case anymore. In spite of carrying out numerous collections of ladybirds on limes in the cities of Breda, Eindhoven and Maastricht in the south of the Netherlands since 2010, I have only observed numerous $A$. bipunctata on lime trees on a single occasion (Table 1). Fig. 1b shows data for A. bipunctata on limes collected in the same places and at the same time as the data for $H$. axyridis shown in Fig. 1a. Numbers are universally low and show none of the effects of urbanisation observed before the arrival of $H$. axyridis.
Table 1. Observations by the author of significant populations of A. bipunctata in the southern Netherlands in the period 2010-2016 after the invasion of $H$. axyridis. The (qualitative) criterion for inclusion here is that a sufficient number of adult ladybirds were observed over a number of plants in the same area not to be considered an isolated or chance occurrence, although exact numbers were not recorded. Immature stages are not considered here due to the problems of field differentiation between them and the same stages of the sibling species Adalia decempunctata (L.) (10-spot ladybird), although at some sites $A$. bipunctata immature stages appeared be present. Only one observation was made on lime trees where $A$. bipunctata was hitherto abundant; others were made on a diversity of plants where $A$. bipunctata has been less regularly looked for. All observations were incidental, that is $A$. bipunctata was not being specifically searched for. Timing (e.g., an absence of observations in 2013-2014) is a reflection of periods when the author was or was not active in the field. It is also worth noting that only lime trees are regularly searched by the author, thus the observation of $A$. bipunctata on lime trees likely constitutes a much lower incidence of this species than on the other plants.

\begin{tabular}{|c|c|c|}
\hline Date & Location & Plant \\
\hline July-Aug 2011 & $\begin{array}{c}\text { Breda (centre) } \\
51.5937^{\circ} \mathrm{N}, 4.7723^{\circ} \mathrm{E}\end{array}$ & $\begin{array}{c}\text { Tansy } \\
\text { (Tanacetum vulgare) }\end{array}$ \\
\hline July 2012 & $\begin{array}{c}\text { Eindhoven (centre) } \\
51.4455^{\circ} \mathrm{N}, 5.4827^{\circ} \mathrm{E}\end{array}$ & $\begin{array}{c}\text { Tansy } \\
\text { (Tanacetum vulgare) }\end{array}$ \\
\hline July 2012 & $\begin{array}{c}\text { Maastricht (centre) } \\
50.8406^{\circ} \mathrm{N}, 5.6960^{\circ} \mathrm{E}\end{array}$ & Lime (Tilia sp.) \\
\hline May-June 2015 & Eindhoven (centre) & Hazel \\
\hline May-June 2016 & $51.4488^{\circ} \mathrm{N}, 5.4841^{\circ} \mathrm{E}$ & (Corylus avellana) \\
\hline June-July 2016 & $\begin{array}{l}\text { Maastricht (suburban) } \\
50.8375^{\circ} \mathrm{N}, 5.7095^{\circ} \mathrm{E}\end{array}$ & $\begin{array}{c}\text { Elder } \\
\text { (Sambuca nigra) }\end{array}$ \\
\hline July 2016 & $\begin{array}{l}\text { Eindhoven (suburban) } \\
51.4333^{\circ} \mathrm{N}, 5.5225^{\circ} \mathrm{E}\end{array}$ & $\begin{array}{c}\text { Poplar } \\
\text { (Populus sp.) }\end{array}$ \\
\hline
\end{tabular}

However, this picture is not complete. On other plants, I have observed a number of outbreaks of $A$. bipunctata (Table 1). In these cases, numbers of accompanying $H$. axyridis were often low, suggesting that on these plants $A$. bipunctata could have some form of competitive advantage. As a generalist, A. bipunctata has probably always occurred in these habitats: my own memories from before the arrival of $H$. axyridis suggest this was the case. However, it was less frequently observed or collected in these habitats due to the focus of researchers on hitherto large and abundant populations elsewhere, especially those easily collected on trees such as urban limes, and sycamores where A. bipunctata was also previously abundant (e.g., Dixon, 1970). More recent assessments of $A$. bipunctata have used the same urban trees (e.g., Roy et al., 2012 used urban limes and sycamores), likely overestimating the decline because other habitats have been underrepresented in surveys.

Thus our picture of $A$. bipunctata decline may be overly pessimistic. Certainly $A$. bipunctata has declined due to $H$. axyridis on certain urban trees. However, the decline in A. bipunctata has been from an artificially elevated level, the ladybird having previously risen to high numbers as a consequence of the same human-related environmental effects that subsequently favoured $H$. axyridis. In habitats elsewhere, $A$. bipunctata persists, probably as it did before 
human interference, on sporadic outbreaks of aphids, relatively unthreatened by $H$. axyridis.

\section{DISCUSSION}

I have focused here on the effects of $H$. axyridis on $A$. bipunctata, as a way of examining in detail whether researchers' assessments of an acute threat posed by $H$. axyridis to other ladybird species are fully justified. Adalia bipunctata was for a long time a widely used research model and its apparent disappearance was likely for many researchers a personal manifestation of the effects of $H$. $a x$ yridis. Furthermore, A. bipunctata was a common species closely associated with man, thus highly visible. This made the effects of $H$. axyridis in such habitats very obvious. It was apparently clear that A. bipunctata was under threat.

But such a view is based on a very static view of the ladybird fauna that takes a 'before and after' view of invasive species, and sees their effects in isolation. The ladybird fauna prior to invasion was not a 'natural' one, but was already the product of many centuries of human influence, in agriculture and, as argued here, through other forms of development in cities, particularly those leading to pollution.

Certainly $A$. bipunctata has undergone habitat compression (sensu Evans et al., 2011); that is, the species has been forced back into habitat (aphid host plant) refugia. However, viewed in the longer term the threat posed by $H$. axyridis to $A$. bipunctata is neither so great nor so serious as has been proposed. The native ladybird appears to have been forced from urban trees particularly, where it only reached high numbers because of human effects enhancing aphid populations. Its presence there was not 'natural' but the product of human influence. During the 1999 study in London, Greg Hurst, the senior researcher, likened $A$. bipunctata to a "ladybird rat" in conversation. This is a fitting analogy, which may be taken further. It is analogous to the black rat (Rattus rattus L.). This human commensal was ultimately replaced in Europe and North America by the more aggressive, larger brown rat (Rattus norvegicus (Berkenhout)), another species closely related with humans (Hedrich, 2000; Feng \& Himsworth, 2014). In this analogy, $H$. axyridis is the brown rat: a bigger, more rapacious human commensal replacing a smaller, pre-existing one.

The ideas developed here for European $A$. bipunctata receive support from other parts of the world where the two ladybirds also coexist. There is some evidence that $A$. bipunctata in North America have been subject to habitat compression by $H$. axyridis, in this case retreating from agricultural habitats, while persisting or appearing in arboreal ones (Obrycki et al., 2000; Hesler \& Kieckhefer, 2008; Bahlai et al., 2015). Although the focus has been on anthropogenic urban ecosystems in this paper, the same considerations apply to agricultural ecosystems, where aphid and ladybird populations are also enhanced through human actions (e.g., Pimentel, 1971; Duffield et al., 1997). Furthermore, A. bipunctata has been slowly spreading in Japan, where it is an exotic, despite facing an abundant na- tive population of $H$. axyridis (Toda \& Sakuratani, 2006): this latter observation suggests that $H$. axyridis is unlikely to ever render $A$. bipunctata extinct.

The observations made here for A. bipunctata are not unique. Evans (2004) studying the effects of the European invasive Coccinella septempunctata in North America found that American native coccinellids displaced by $C$. septempunctata from alfalfa returned if the level of the prey pea aphid, Acyrthosiphon pisum (Harris), was artificially increased. He had previously observed that native species were more abundant in other, endemic vegetation (Evans, 2000). Further research using historical collections and literature suggested that at least one native species, Coccinella novemnotata Herbst, was previously more common in alfalfa in the 1950 s as it exploited a population explosion of the invasive spotted alfalfa aphid Therioaphis maculata (Buckton) (Evans, 2013). Based on these observations it may be deduced that American native species at artificially high levels due to abundant aphids in crops were once again restricted to ancestral habitats in the face of an invader.

Not all observations support habitat compression (e.g., Finlayson et al., 2008) and certainly other factors are likely at play in the decline of $A$. bipunctata. Honek et al. (2016), using datasets extending over 39 years, have shown that A. bipunctata was already declining in Europe before the arrival of $H$. axyridis. It is tempting to suggest that this decline might have occurred because of decreasing air pollution or other anthropogenic effects, leading to lower aphid populations generally. In this case, it would not be an effect totally divorced from those discussed here. Such a study emphasises that the situation is not a simple one and a broader context is necessary than one narrowly focused on $H$. axyridis.

This broader context should certainly focus on a longer time perspective, as discussed above. Ladybird populations have been in flux since prehistory (Majerus, 1994) and will continue to be so with or without invasive species (Acorn, 2007). A better understanding of such changes is needed, including using entomological collections and literature in the manner of Evans (2013) for C. novemnotata. Collection specimens of $A$. bipunctata, for example, date back as far as the $17^{\text {th }}$ century (Hammond, 1975). Hand-in-hand with this is a need to establish what other threats are posed to ladybirds. Loss of natural habitats may be a particularly influential factor. However this and other factors such as climate change (Roy \& Majerus, 2010) are currently much less well researched than the effects of invasive ladybirds.

Because of its widespread nature and abundance, as well as its invasiveness, studies of $H$. axyridis are often in advance of studies of other members of the Coccinellidae. We frequently lack the context in which to assess which characteristics of $H$. axyridis make it so successful or pose a potential threat, because we lack studies of the same features of other non-invasive species (Sloggett, 2005, 2012). Thus a number of studies show that $H$. axyridis is an intraguild predator of $A$. bipunctata in the field (e.g., Hautier et al., 2011; Thomas et al., 2013; Rondoni et al., 2015). 
However, we do not know if this poses a unique threat to $A$. bipunctata or not, because there is no work on intraguild predation of $A$. bipunctata in the field by native species of ladybirds: indeed there are relatively few laboratory studies (but see Hemptinne et al., 2000; Rondoni et al., 2012). It is perhaps ironic that the native species valued by so many $H$. axyridis researchers are so rarely studied themselves.

Underlying these issues is a lack of precision in defining the nature of the threat that $H$. axyridis poses. When we discuss a decline in native ladybirds are we implying that species will go extinct? Researchers may benefit from this association in the minds of policy makers or the general public but, in fact, we have no historical records of any ladybird ever going extinct (Honek et al., 2017). Could it be that $H$. axyridis poses an insufficient threat alone, but when combined with other threats, it will cause species extinctions? Or will similar levels of biodiversity be maintained, albeit with some species reduced to smaller numbers than before (as might be inferred from A. bipunctata)? This ambiguity needs to be resolved. Although often considered bad per se, a decline in numbers is not necessarily a catastrophe.

In conclusion, more care is required in assessing and describing the likely effects of ladybird invaders generally and $H$. axyridis in particular. Numerous papers have taken an uncompromising stance on the dire effects of the invader: a more nuanced view of its effects has been slow to emerge. Early on in its colonization of Europe, H. axyridis was given the title of the "most invasive ladybird on earth" (Roy et al., 2006). This title itself well illustrates the need for a wider perspective. For a ladybird researcher, it suggests that the ladybird is a serious environmental threat, but when coccinellids are viewed as a 6000-species strong single family compared to the likely millions of species in existence (Nedvěd \& Kovár̆, 2012; Caley et al., 2014), the claim seems rather small. We need to ask ourselves if $H$. axyridis is as big a problem as initially it appeared to be, or whether other invasives pose a more serious threat.

ACKNOWLEDGEMENTS. I thank I. Zeilstra for her help with the recent practical work discussed here and for her comments on drafts of this manuscript. This paper was originally presented at the 13th Ecology of Aphidophaga symposium at Freising, Germany in August 2016, and I would also like to thank those at this meeting who gave me comments on my presentation at that time.

\section{REFERENCES}

ACORN J. 2007: Ladybugs of Alberta: Finding the Spots and Connecting the Dots. University of Alberta Press, Edmonton, 169 pp.

Adriaens T., San Martin y Gomez G. \& Maes D. 2008: Invasion history, habitat preferences and phenology of the invasive ladybird Harmonia axyridis in Belgium. - BioControl 53: 69-88.

Adriaens T., San Martin G., Hautier L., Branquart E. \& Maes D. 2010: Toward a Noah's Ark for native ladybirds in Belgium? - IOBC-WPRS Bull. 58: 1-3.

Adriaens T, San Martin y Gomez G., Bogaert J., Crevecoeur L., Beuckx J.-P. \& Maes D. 2015: Testing the applicability of regional IUCN Red List criteria on ladybirds (Coleoptera, Coc- cinellidae) in Flanders (north Belgium): opportunities for conservation. - Insect Conserv. Divers. 8: 404-417.

AKkeRmans R. 2016: The larger ladybirds in and around Roermond. - Natuurhist. Maandblad 105: 93-99 [in Dutch, English abstr.].

Bahlai C.A., Colunga-Garcia M., Gage S.H. \& Landis D.A. 2015: The role of exotic ladybeetles in the decline of native ladybeetle populations: evidence from long-term monitoring. - Biol. Invasions 17: 1005-1024.

Bell J.N.B., McNeill S., Houlden G., Brown V.C. \& Mansfield P.J. 1993: Atmospheric change: effect on plant pests and diseases. - Parasitology 106: S11-S24.

BRAKeFIELD P.M. 1984: Ecological studies on the polymorphic ladybird Adalia bipunctata in the Netherlands. I. Population biology and geographical variation of melanism. - J. Anim. Ecol. 53: 761-774.

Brown P.M.J., Roy H.E., Rothery P., Roy D.B., Ware R.L. \& Majerus M.E.N. 2008: Harmonia axyridis in Great Britain: analysis of the spread and distribution of a non-native coccinellid. - BioControl 53: 55-67.

Caley M.J., Fisher R. \& Mengersen K. 2014: Global species richness estimates have not converged. - Trends Ecol. Evol. 29: $187-188$.

CARTER C.I. 1992: Lime Trees and Aphids. Arboricultural Research Note 104, The Arboricultural Association, Stroud Green, Glos., U.K., 3 pp. URL: http://www.trees.org.uk/Trees. org.uk/files/c4/c439d44f-19ef-4002-9ad3-4ba293650242.pdf

Chakir R., David M., Gozlan E. \& Sangare A. 2016: Valuing the impacts of an invasive biological control agent: a choice experiment on the Asian ladybird in France. - J. Agric. Econ. 67: 619-638.

Cottrell T.E. \& Yeargan K.V. 1998a: Intraguild predation between an introduced lady beetle Harmonia axyridis (Coleoptera: Coccinellidae) and a native lady beetle, Coleomegilla maculata (Coleoptera: Coccinellidae). - J. Kans. Entomol. Soc. 71: 159-163.

Cottrell T.E. \& Yeargan K.V. 1998b: Influence of a native weed, Acalypha ostryaefolia (Euphorbiaceae) on Coleomegilla maculata (Coleoptera: Coccinellidae) population density, predation and cannibalism in sweet corn. - Environ. Entomol. 27: $1375-1385$.

Czechowska W. \& Bielawski R. 1981: Coccinellids (Coleoptera, Coccinellidae) of Warsaw and Mazovia. - Memor. Zool. 34: 181-197.

Dale A.G. \& Frank S.D. 2014: The effects of urban warming on herbivore abundance and street tree condition. - PLOS ONE 9(7): e102996, $10 \mathrm{pp}$.

Dixon A.F.G. 1970: Factors limiting the effectiveness of the coccinellid beetle, Adalia bipunctata (L.), as a predator of the sycamore aphid, Drepanosiphum platanoides (Schr.). - J. Anim. Ecol. 39: 739-751.

Duffield S.J., Bryson R.J., Young J.E.B., Sylvester-Bradley R. \& Sсотт R.K. 1997: The influence of nitrogen fertilizer on the population development of the cereal aphids Sitobion avenae (F.) and Metopolophium dirhodum (Wlk.) on field grown winter wheat. - Ann. Appl. Biol. 130: 13-26.

Egerer M.H., Bichier P. \& Philpott S.M. 2017: Landscape and local habitat correlates of lady beetle abundance and species richness in urban agriculture. - Ann. Entomol. Soc. Am. 110: 97-103.

EHLERS R.-U. 2011: Cost-benefit, risk and trade-off analysis of regulation. In Ehlers R.-U. (ed.): Regulation of Biological Control Agents. Springer, Dordrecht, pp. 139-153.

Evans E.W. 2000: Morphology of invasion: body size patterns associated with establishment of Coccinella septempunctata 
(Coleoptera: Coccinellidae) in western North America. - Eur. J. Entomol. 97: 469-474.

Evans E.W. 2004: Habitat displacement of North American ladybirds by an introduced species. - Ecology 85: 637-647.

Evans E.W. 2013: What happens to rare species when invaders arrive? Coccinella novemnotata in western North America as a case study. - IOBC-WPRS Bull. 94: 61.

Evans E.W., Soares A.O. \& Yasuda H. 2011: Invasions by ladybugs, ladybirds, and other predatory beetles. - BioControl 56: 597-611.

Feng A.Y.T. \& Himsworth C.G. 2014: The secret life of the city rat: a review of the ecology of urban Norway and black rats (Rattus norvegicus and Rattus rattus). - Urban Ecosyst. 17: 149-162.

FinLAYSON C.J., LANDRY K.M. \& AlYOKHIN A.V. 2008: Abundance of native and non-native lady beetles (Coleoptera: Coccinellidae) in different habitats in Maine. - Ann. Entomol. Soc. Am. 101: 1078-1087.

GoEtz D.W. 2009: Seasonal inhalant insect allergy: Harmonia axyridis ladybug. - Curr. Opin. Allergy Clin. Immunol. 9: 329-333.

Gozlan R.E., Burnard D., Andreou D. \& Britton J.R. 2013: Understanding the threats posed by non-native species: public vs. conservation managers. - PLOS ONE 8(1): e53200, 10 pp.

Grez A.A., Zaviezo T., Roy H.E., Brown P.M.J. \& Bizama G. 2016: Rapid spread of Harmonia axyridis in Chile and its effects on local coccinellid biodiversity. - Diversity Distrib. 22: 982-994.

Hautier L., San Martin G., Callier P., de Biseau J.-C. \& GréGOIRE J.-C. 2011: Alkaloids provide evidence of intraguild predation on native coccinellids by Harmonia axyridis in the field. - Biol. Invasions 13: 1805-1814.

Hammond P.M. 1975: Seventeenth century British Coleoptera from the collection of Leonard Plukenet (1642-1706). - Entomol. Gaz. 26: 261-268.

Harmon J.P., Stephens E. \& Losey J. 2007: The decline of native coccinellids (Coleoptera: Coccinellidae) in the United States and Canada. - J. Insect Conserv. 11: 85-94.

Hedrich H.J. 2000: History, strains and models. In Krinke G.J. (ed.): The Laboratory Rat. Academic Press, San Diego, pp. 3-16.

Hemptinne J.-L., Lognay G., Gauthier C. \& Dixon A.F.G. 2000: Role of surface chemical signals in egg cannibalism and intraguild predation in ladybirds (Coleoptera: Coccinellidae). Chemoecology 10: 123-128.

HeSLER L.S. \& KIECKHEFER R.W. 2008: Status of exotic and previously common native coccinellids (Coleoptera) in South Dakota landscapes. - J. Kans. Entomol. Soc. 81: 29-49.

HodeK I., van EMden H.F. \& HoNĚK A. (eds) 2012: Ecology and Behaviour of the Ladybird Beetles. Wiley-Blackwell, Chichester, $561 \mathrm{pp}$.

HoNĚK A. 2012: Distribution and habitats. In Hodek I., van Emden H.F. \& Honěk A. (eds): Ecology and Behaviour of the Ladybird Beetles. Wiley-Blackwell, Chichester, pp. 110-140.

HonĚK A. \& Hodek I. 1996: Distribution in habitats. In Hodek I. \& Honěk A. (eds): Ecology of Coccinellidae. Kluwer Academic Publishers, Dordrecht, pp. 95-141.

Honek A., Martinkova Z., Dixon A.F.G., Roy H.E. \& PekÁr S. 2016: Long-term changes in communities of native coccinellids: population fluctuations and the effect of competition from an invasive non-native species. - Insect Conserv. Divers. 9: 202-209.

Honek A., Dixon A.F.G., Soares A.O., Skuhrovec J. \& MartinKovA Z. 2017: Spatial and temporal changes in the abundance and composition of ladybird (Coleoptera: Coccinellidae) communities. - Curr. Opin. Insect Sci. 20: 61-67.

Howe A.G., RANSIJN J. \& Ravn H.P. 2015: A sublethal effect on native Anthocoris nemoralis through competitive interactions with invasive Harmonia axyridis. - Ecol. Entomol. 40: 639649.

KANEKo S. 2013: Occurrence of the exotic predatory ladybird Platynaspidius maculosus (Coleoptera: Coccinellidae) in citrus groves in Shizuoka City, Central Japan: seasonal prevalence of adults captured on sticky traps. - Appl. Entomol. Zool. 48: 189-194.

Katsanis A., Babendreier D., Nentwig W. \& Kenis M. 2013: Intraguild predation between the invasive ladybird Harmonia axyridis and non-target European coccinellid species. - BioControl 58: 73-83.

Kawakami Y., Yamazaki K. \& Ohashi K. 2016: Population dynamics, seasonality and aphid prey of Cheilomenes sexmaculata (Coleoptera: Coccinellidae) in an urban park in central Japan. - Eur. J. Entomol. 113: 192-199.

KLAPWIJK J. 2013: The risks of regulation for invertebrate biological control. - IOBC-WPRS Bull. 94: 5-6.

Косн R.L. 2003. The multicolored Asian lady beetle, Harmonia axyridis: a review of its biology, uses in biological control, and non-target impacts. - J. Insect Sci. 3(32), 16 pp.

Koch R.L. \& Galvan T.L. 2008: Bad side of a good beetle: the North American experience with Harmonia axyridis. - BioControl 53: 23-35.

Koch R.L., Venette R.C. \& Hutchison W.D. 2006: Predicted impact of an exotic generalist predator on monarch butterfly (Lepidoptera: Nymphalidae) populations: a quantitative risk assessment. - Biol. Invasions 8: 1179-1193.

Kozlov M.V. 2015: Changes in ladybird (Coleoptera: Coccinellidae) communities along a steep pollution gradient in subarctic forests of European Russia. - Eur. J. Entomol. 112: 728-733.

Krafsur E.S., Nariboli P. \& Obrycki J.J. 1996: Gene flow and diversity at allozyme loci in the twospotted lady beetle (Coleoptera: Coccinellidae). - Ann. Entomol. Soc. Am. 89: 410-419.

Linder C., Lorenzini F. \& Kehrli P. 2009: Potential impact of processed Harmonia axyridis on the taste of 'Chasselas' and 'Pinot noir' wines. - Vitis 48: 101-102.

Majerus M.E.N. 1994: Ladybirds. New Naturalist Series no. 81, HarperCollins, London, $367 \mathrm{pp}$.

Majerus M., Strawson V. \& RoY H. 2006: The potential impacts of the arrival of the harlequin ladybird, Harmonia axyridis (Pallas) (Coleoptera: Coccinellidae), in Britain. - Ecol. Entomol. 31: 207-215.

Martins C.B.C., Almeida L.M., Zonta-de-Carvalho R.C., Castro C.F. \& Pereira R.A. 2009: Harmonia axyridis: a threat to Brazilian Coccinellidae? - Rev. Bras. Entomol. 53: 663-671.

MCCutcheon T.W. \& SCotT H.R. 2001: Observation of Cosmetic Damage on a House Caused by the Multicolored Asian Lady Beetle, Harmonia axyridis (Coleoptera, Coccinellidae). West Virginia University Extension Service, Morgantown, West Virginia.

Michaud J.P. 2002: Invasion of the Florida citrus ecosystem by Harmonia axyridis (Coleoptera: Coccinellidae) and asymmetric competition with a native species, Cycloneda sanguinea. - Environ. Entomol. 31: 827-835.

Mukwevho V.O., Pryke J.S. \& Roets F. 2017: Habitat preferences of the invasive harlequin ladybeetle Harmonia axyridis (Coleoptera: Coccinellidae) in the Western Cape Province, South Africa. - Afr. Entomol. 25: 86-97.

NEDVĚD O. \& KovÁR̆ I. 2012: Phylogeny and classification. In Hodek I., van Emden H.F. \& Honěk A. (eds): Ecology and Be- 
haviour of the Ladybird Beetles. Wiley-Blackwell, Chichester, U.K., pp. 1-12.

Obrycki J.J., Elliot N.C. \& Giles K.L. 2000: Coccinellid introductions: potential for and evaluation of nontarget effects. In Follett P.A. \& Duan J.J. (eds) Nontarget Effects of Biological Control. Springer Science+Business Media, New York, pp. 127-145.

Omkar \& Pervez A. 2005: Ecology of two-spotted ladybird, Adalia bipunctata: a review. - J. Appl. Entomol. 129: 465-474.

Pimentel D. 1971: Population control in crop systems: monocultures and plant spatial patterns. - Proc. Tall Timbers Conf. Ecol. Anim. Control Habitat Manag. 2: 209-221.

Purse B.V., Comont R., Butler A., Brown P.M.J., Kessel C. \& Roy H.E. 2015: Landscape and climate determine patterns of spread for all colour morphs of the alien ladybird Harmonia axyridis. - J. Biogeogr. 42: 575-588.

Rondoni G., ONOFRI A. \& RicCI C. 2012: Laboratory studies on intraguild predation and cannibalism among coccinellid larvae (Coleoptera: Coccinellidae). — Eur J. Entomol. 109: 353-362.

Rondoni G., Athey K.J., Harwood J.D., Conti E., Ricci C. \& OBRYCKI J.J. 2015: Development and application of molecular gut-content analysis to detect aphid and coccinellid predation by Harmonia axyridis (Coleoptera: Coccinellidae) in Italy. Insect Sci. 22: 719-730.

Roy H.E. \& Brown P.M.J. 2015: Ten years of invasion: Harmonia axyridis (Pallas) (Coleoptera: Coccinellidae) in Britain. Ecol. Entomol. 40: 336-348.

Roy H.E. \& MaJerus M.E.N. 2010: Coccinellids in a changing world. In Kindlmann P., Dixon A.F.G. \& Michaud J.P. (eds): Aphid Biodiversity Under Environmental Change: Patterns and Processes. Springer, Dordrecht, pp. 149-170.

Roy H., Brown P. \& Majerus M. 2006: Harmonia axyridis: a successful biocontrol agent or an invasive threat? In Eilenberg J. \& Hokkanen H.M.T. (eds): An Ecological and Societal Approach to Biological Control. Springer, Dordrecht, pp. 295-309.

Roy H.E., Adriaens T., Isaac N.J.B., Kenis M., Onkelinx T., San Martin G., Brown P.M.J., Hautier L., Poland R., Roy D.B. ET AL. 2012: Invasive alien predator causes rapid declines of native European ladybirds. — Divers. Distrib. 18: 717-725.

Roy H.E., Brown P.M.J., Adriaens T., Berkvens N., Borges I., Clusella-Trullas S., Comont R.F., De Clerce P., Eschen R., Estoup A. ET AL. 2016: The harlequin ladybird, Harmonia axyridis: global perspectives on invasion history and ecology. Biol. Invasions 18: 997-1044.

Sloggett J.J. 2005: Are we studying too few taxa? Insights from aphidophagous ladybird beetles (Coleoptera: Coccinellidae). — Eur. J. Entomol. 102: 391-398.
SLOGGetT J.J. 2008: Habitat and dietary specificity in aphidophagous ladybirds (Coleoptera: Coccinellidae): explaining specialization. - Proc. Neth. Entomol. Soc. Meet. 19: 95-113.

SlogGetT J.J. 2012: Harmonia axyridis invasions: deducing evolutionary causes and consequences. - Entomol. Sci. 15: 261-273.

Sloggett J.J. \& HonĚK A. 2012: Genetic studies. In Hodek I., van Emden H.F. \& Honěk A. (eds): Ecology and Behaviour of the Ladybird Beetles. Wiley-Blackwell, Chichester, pp. 13-53.

SNYDER W.E. 2009: Coccinellids in diverse communities: which niche fits? - Biol. Control 51: 323-335.

Thomas A.P., Trotman J., Wheatley A., Aebi A., Zindel R. \& Brown P.M.J. 2013: Predation of native coccinellids by the invasive alien Harmonia axyridis (Coleoptera: Coccinellidae): detection in Britain by PCR-based gut analysis. - Insect Conserv. Divers. 6: 20-27.

Timoféeff-Ressovsky N.W. 1940: Zur Analyse des Polymorphismus bei Adalia bipunctata L. - Biol. Zentbl. 60: 130-137.

TODA Y. \& SAKURATANI Y. 2006: Expansion of the geographical distribution of an exotic ladybird beetle, Adalia bipunctata (Coleoptera: Coccinellidae), and its interspecific relationships with native ladybird beetles in Japan. - Ecol. Res. 21: 292300.

Veran S., Piry S., Ternois V., Meynard C.N., Facon B. \& Estoup A. 2016: Modeling spatial expansion of invasive alien species: relative contributions of environmental and anthropogenic factors to the spreading of the harlequin ladybird in France. Ecography 39: 665-675.

WARE R.L. \& MAJERUS M.E.N. 2008: Intraguild predation of immature stages of British and Japanese coccinellids by the invasive ladybird Harmonia axyridis. — BioControl 53: 169-188.

Welch V.L., Sloggett J.J., Webberley K.M. \& Hurst G.D.D. 2001: Short-range clinal variation in the prevalence of a sexually transmitted fungus associated with urbanisation. - Ecol. Entomol. 26: 547-550.

Wilkaniec B., Borowiak-Sobkowiak B., Wilkaniec A., Breś W., FRUŻYŃSKA-JÓŹWIAK D. 2013: The evaluation of factors determining the health condition of Acer platanoides and Tilia cordata plantings in selected sites of urban greenery in Poznań, Poland. - J. Plant Prot. Res. 53: 60-64.

Yasuda H., Evans E.W., KajtTa Y., Urakawa K. \& Takizawa T. 2004: Asymmetric larval interactions between introduced and indigenous ladybirds in North America. - Oecologia 141: 722-731.

Received June 11, 2017; revised and accepted October 13, 2017 Published online October 30, 2017 